\title{
Implementation of Restorative Justice In Traffic Accident Settlement
}

\author{
Indra Jaya Syafputra*), Maryanto**), and Jawade Hafidz ${ }^{* * *}$ ) \\ *) Head of Traffic Police of Rembang, E-mail: indrajaya mh36@std.unissula.ac.id \\ $\left.{ }^{* *}\right)$ Faculty of Law Universitas Islam Sultan Agung \\ ${ }^{* *}$ Faculty of Law Universitas Islam Sultan Agung
}

\begin{abstract}
This study aims to determine and analyze the implementation of restorative justice in resolving traffic accident cases in the jurisdiction of the Rembang Police and the obstacles that arise in the implementation of restorative justice in resolving traffic accident cases in the jurisdiction of the Rembang Police and their solutions. The approach method used is sociological juridical, descriptive analytical research specifications, types and sources of data using primary and secondary data, data collection methods are field studies and literature studies, while the data analysis method uses qualitative analysis. The results of the study indicate that the implementation of restorative justice in resolving traffic accident cases in the jurisdiction of the Rembang Police is aimed at justice by referring to the Criminal Procedure Code, the LLAJ Law, the Police Law, and the National Police Perkap Number 6 of 2019. In its application there are obstacles, namely the lack of legal awareness of community and intervention from third parties.

Keywords: Implementation; Restorative Justice; Traffic Accidents.
\end{abstract}

\section{Introduction}

Road traffic and transportation have a strategic role in supporting development, so the potential and role of road traffic and transportation must be developed in order to realize security, welfare, traffic order and road transportation. ${ }^{1}$ The importance of the role of road traffic and transportation is reflected in the provisions of Article 3 of Act No. 22 of 2009 concerning Road Traffic and Transportation (LLAJ Law) which states that road traffic and transportation are carried out with the aim of realizing safe traffic and road transportation services, safe, orderly, smooth, and integrated; the realization of traffic ethics and national culture; and the realization of law enforcement and legal certainty for the community.

The development of world life that requires a balance of transportation besides having a positive impact also has a negative impact. More and more people are using road transportation, but unfortunately it is not balanced with adequate knowledge for motorized vehicle users about how to drive properly. This has the potential to cause traffic accidents. ${ }^{2}$

\footnotetext{
${ }^{1}$ Preliyanto Puji Utomo and Bambang Tri Bawono, "Application Of Act No. 22 Of 2009 As A Traffic Accidents Countermeasures Management In The Blora Police Law Area” Daulat Hukum, Vol 3 No. 2 (2020), url : http://jurnal.unissula.ac.id/index.php/RH/article/view/9373.

2 Hari Condro Wibowo, 2019, "Proses Penyidikan Pelaku Kecelakaan Lalu Lintas Anak di Bawah Umur di Kepolisian Resor Kebumen", Tesis, Semarang : Unissula, h.4, url : http://repository.unissula.ac.id/16313/5/bab\%20I.pdf
} 
Traffic accidents according to the provisions of Article 1 number 22 of the LLAJ Law are unexpected and unintentional road events involving vehicles with or without road users resulting in human casualties and/or property loss. One of the main causes of road traffic accidents is the human factor. ${ }^{3}$

Traffic accidents that have occurred so far are among others caused by negligence, carelessness, inattention experienced by the driver. In general, traffic accidents involving private and public vehicles are caused by several factors, including drivers, pedestrians, and unsupported infrastructure. The main factor for driver error is the lack of care in driving the vehicle. ${ }^{4}$

The issue of road traffic accidents (accidents) is still a big job for the Police. In Central Java, data from the Central Java Regional Police showed that the number of traffic accidents in Central Java in 2019 was 21,694 cases, while in 2020 there were 19,843 cases. ${ }^{5}$ This shows a downward trend in traffic accident cases that occurred in 2019-2020.

In Rembang Regency, the number of traffic accidents also shows a decline. This can be seen from the traffic accident data in 2019 as many as 423 cases while in 2020 it was around 365 cases. From these data, It is recorded that the death toll in 2019 was 31 people and in 2020 as many as 19 people. For serious injuries in 2019, there were 22 people, while in 2020 there were around 5 people, while the victims of minor injuries in 2019 were 506 people and in 2020 as many as 442 people. 6

Traffic accidents are one of the big problems that must be faced by the Rembang Regency Government, in this case the Rembang Police Traffic Unit. ${ }^{7}$ In the event of a traffic accident, the police officer is obliged to handle traffic accidents, one of which is by conducting a case investigation as regulated in Article 227 of the LLAJ Law. However, based on the provisions of Article 109 paragraph (2) of the Criminal Procedure Code, investigators are given the authority to stop investigations for several reasons.

In practice, not all traffic accident cases are resolved through a judicial process. Based on a preliminary survey at the Rembang Police Satlatas, it shows that from January to April 2021 there were 104 traffic accidents, all of which ended with SP 3 (termination of investigation).In criminal law, in responding to a crime that is considered to be restored, there is a paradigm of punishment called

\footnotetext{
${ }^{3}$ Mukhammad H. Saputra, "Analisis Sistem Informasi Faktor Risiko Kecelakaan Lalu Lintas di Dinas Kesehatan Kota Mojokerto", Medika Majapahit, Vol 8. No. 2, September 2016, url : https://123dok.com/document/zk6red8y-sekolah-tinggi-ilmu-kesehatan-majapahitmojokerto.html

4 Syakiar, Unit Pratimaratri, Deaf Wahyuni Ramadhani, Pelaksanaan Penyidikan Terhadap Anak Pelaku Pelanggaran Lalu Lintas Yang Mengakibatkan Korban Meninggal Dunia (Studi : Polresta Padang), Jurnal Penelitian, (http://www.ejurnal.bunghatta.ac.id, accessed 20 May 2021).

5 Polda Jateng Kasus Kecelakaan Meninggal Terbanyak Terjadi di Tol, (https://news.detik.com, accessed 20 May 2021)

6 Tak Ada Tilang Kecelakaan Lalu Lintas di Rembang Turun, (https://radarkudus.jawapos.com, accessed 20 May 2021).

${ }^{7}$ Dadik Purnomo dan Jawade Hafidz, Peran Sat Lantas Polres Rembang Dalam Menekan Angka Kecelakaan Lalu Lintas, Jurnal Daulat Hukum, Voume 1 No. 1 March, 2018, url : http://jurnal.unissula.ac.id/index.php/RH/article/view/2647
} 
restorative justice, in which the perpetrator is encouraged to repair the harm he has caused to the victim, his family, and the community ${ }^{8}$.

Restorative Justice is a popular alternative in various parts of the world which is often used in handling cases of children who are in trouble with the law because it offers a comprehensive and effective solution. The concept of restorative justice aims to empower victims, perpetrators, families, and communities to correct an act against the law by using awareness and conviction as a basis for improving community life. ${ }^{9}$

In the case of a traffic accident, there was no intention of the perpetrator in carrying out the action at first, but due to negligence or lack of caution eventually resulted in the accident. Under the LLAJ Law, such acts are punishable by imprisonment. However, in its development the concept of restorative justice chose imprisonment as the last option because the important point was to reconcile the two parties and the victim's family. Reconciliation can be done by compensating and fulfilling obligations to the rights of the victim or the victim's family. ${ }^{10}$

However, the concept of restorative justice is still very difficult to implement, because the laws and regulations governing restorative justice only exist in the juvenile justice system, not traffic accident cases. This study aims to determine and analyze the implementation of restorative justice in resolving traffic accident cases in the jurisdiction of the Rembang Police and the obstacles that arise in the implementation of restorative justice in resolving traffic accident cases in the jurisdiction of the Rembang Police and their solutions.

\section{Research Methods}

The approach method used in this research is sociological juridical, namely: research that examines how the law works in society. ${ }^{11}$ The research specification is descriptive analytical, namely research that aims to make a systematic picture or painting of a phenomenon that occurs in society. ${ }^{12}$ Sources and types of data used are primary data and secondary data. The data collection method is carried out through field studies and literature studies while the data analysis method uses qualitative analysis.

\section{Result and Discussion}

\footnotetext{
8 A Chuasanga, Ong Argo Victoria. (2019). Legal Principles Under Criminal Law in Indonesia Dan Thailand, Jurnal Daulat Hukum, Vol $2, \quad$ No 1 (2019) http://jurnal.unissula.ac.id/index.php/RH/article/view/4218

${ }_{9}^{9}$ Nikmah Rosidah, 2014, Budaya Hukum Hakim Anak Di Indonesia, Semarang : Pustaka Magister, Semarang, p. 103.

${ }^{10}$ Arman Sahti, Penerapan Konsep Restorative Justice Dalam Penyelesaian Perkara Kecelakaan Lalu Lintas, Aktualita, Vol. 2 No. 2 (December) 2019, url : https://ejournal.unisba.ac.id/index.php/aktualita/article/view/5176/pdf

11 Mukti Fajar ND dan Yulianto Achmad, 2013, Dualisme Penelitian Hukum Normatif dan Empiris, Yogyakarta: Pustaka Pelajar, p.47.

12M. Djunaidi Ghoni dan Fauzan Almansur, 2012, Metodologi Penelitian Kualitatif, ar-Ruzz Media, Yogyakarta, p. 25.
} 


\subsection{Implementation of Restorative Justice in the Settlement of Traffic Accident Cases in the Legal Territory of the Rembang Police}

Traffic accidents based on the provisions of Article 229 of Act No. 22 of 2009 traffic accidents are classified into three, namely:

- Minor traffic accidents are accidents that result in damage to vehicles and/or goods.

- Moderate traffic accidents, namely accidents that result in minor injuries and damage to vehicles and/or goods. What is meant by minor injury is an injury that causes the victim to suffer from illness that does not require hospitalization or other than those classified as serious injuries.

- Heavy traffic accidents, namely accidents that result in death or serious injury to the victim.

The criminal provisions against traffic accident perpetrators are specifically regulated in Article 310 and Article 311 regulated in the 2009 LLAJ Law. Article 310 of the LLAJ Law regulates traffic accidents where the perpetrator who caused the accident was negligent in driving the vehicle, causing a traffic accident to occur. Meanwhile, if the perpetrator who caused the traffic accident occurred intentionally causing a traffic accident, then the perpetrator is suspected of Article 311 of the LLAJ Law.

Traffic accidents often occur in people's lives. There are several factors that cause traffic accidents, namely: ${ }^{13}$

- The human factor can be seen from the mental attitude and behavior of the driver, knowledge, skills of the driver in traffic and the factor of carelessness.

- Vehicle factors, related to roadworthy conditions of bicycle vehicles such as braking systems, tire conditions, or steering systems that do not work, or even modifications that are not in accordance with safety rules

- Road factors, for example the condition of the road surface that does not meet the requirements (perforated, heavily damaged), inadequate pedestrian facilities, lack of street lighting.

Based on the results of research at the Rembang Police, the settlement of traffic accident cases, whether in the light, medium or severe categories, always seeks mediation through a restorative justice approach. Draft of restorative justice is basically simple. The measure of justice is no longer based on retribution from the victim to the perpetrator (either physically, psychologically or in punishment); however, the painful act is cured by providing support to the victim and requiring the perpetrator to be held accountable, with family and community assistance when needed. ${ }^{14}$

The implementation of restorative justice in resolving traffic accident cases at the Rembang Police is carried out based on the Criminal Procedure Code, Act No. 2 of 2002 concerning the Indonesian National Police, and the National Police Perkap Number 6 of 2019 concerning Criminal Investigations. In this stage of the

\footnotetext{
13 P. Suwardjoko Warpani, 2002, Pengelolaan Lalu Lintas dan Agnkutan Jalan, Bandung : Penerbit ITB, p.108

14 Rudi Rizky (ed), 2008, Refleksi Dinamika Hukum (RangkaianPemikiran dalam Dekade Terakhir), Jakarta: Perum Percetakan Negara Indonesia, p. 4.
} 
investigation, the investigator prioritizes restorative justice, that is, mediation is sought between the perpetrator and the victim and the victim's family. In this case, the investigation process is still carried out according to the provisions in the Criminal Procedure Code, but in the process mediation is carried out on both parties.

The reason for carrying out restorative justice is as stipulated in Article 12 of the National Police Perkap Number 6 of 2019, namely the fulfillment of material and formal requirements. To be able to do restorative justice in the settlement of traffic cases, the material requirements have been met, namely:

- Does not cause public unrest or there is no community rejection

- No impact on social conflict

- There is a statement from all parties involved not to object, and waive the right to sue before the law;

- The limiting principle on the perpetrator is that the level of the perpetrator's error is relatively light, namely the error is in the form of intentional; and the perpetrator is not a recidivist. Whereas in criminal acts, it is an investigation and investigation before the SPDP is sent to the Public Prosecutor.

The formal requirements for restorative justice in handling traffic accident cases are:

- Letter of request for peace from both parties (perpetrator and victim/victim's family);

- Declaration of peace (deed dading) and dispute resolution of the litigants are known by superiors

- Investigator;

- Minutes of additional examination of the litigating parties after the settlement of the case through restorative justice;

- $\mathrm{R} /$ recommendation for the title of a special case that approves the settlement of restorative justice;

- The perpetrator did not object and was carried out voluntarily on responsibility and compensation.

During the investigation process, between the victim and the perpetrator, mediation was sought through deliberation to resolve the case amicably. The investigator after receiving the request for peace between the two parties signed on the seal, conducts administrative research on the formal requirements for resolving the case through restorative justice to be submitted to the leadership for approval. The agreement signed by all parties involved is attached to the file of the examination procedure as the basis for stopping the investigation by the investigator. Investigators then do the filing, which is to complete all the documents for the examination. The investigator then recorded in the register book B-19 as a case of restorative justice which was counted as a case settlement. After the case file is complete.

Traffic accidents are often caused by negligence and no intentional factor. Restorative justice in handling traffic accidents focuses on the needs of victims, perpetrators, and also involves community participation. The victim is involved in the process while the perpetrator is encouraged to take responsibility for his actions, namely by correcting the mistakes that have been made by apologizing, 
providing compensation to the victim by paying for treatment, or compensation for death if the victim dies. Restorative justice in traffic accident cases is based on mutual respect between the perpetrator and the victim so that there will be no disputes in the future.

\subsection{Barriers to the Implementation of Restorative Justice in the Settlement of Traffic Accident Cases in the Rembang Police Legal Area and their Solutions}

The results of research at the Rembang Police show that several obstacles in the implementation of restorative justice in solving traffic accident cases are:

- Lack of understanding of community law

In the application of restorative justice, sometimes there are differences in perception regarding the application of restorative principles in the implementation of the termination of an investigation, for example the view that compensation does not abort a crime. This is contrary to the purpose of the restorative justice approach and has an impact on the loss or destruction of kinship and family values for the litigants.

The solution to overcome these obstacles is an approach to the community either in a familial or social manner so that the community understands that the principle of restorative justice is the principle of settlement to realize community justice.

- There is intervention from a third party

The implementation of restorative justice aims to provide justice and legal certainty for litigants. However, sometimes there are third parties who provoke the victim so that the process continues through the courts. The solution to overcome this is to approach the conflicting parties (perpetrators and victims) so as not to be influenced by third parties who are not interested. In addition, briefing was also carried out to both parties (perpetrators and victims), as well as community leaders involved about the purpose of resolving cases through restorative justice which leads to the principle of justice.

\section{Closing}

The implementation of restorative justice in solving traffic accident cases in the jurisdiction of the Rembang Police is aimed at justice by referring to the Criminal Procedure Code, the LLAJ Law, the Police Act, and the National Police Perkap Number 6 of 2019. In its implementation, obstacles arise, namely the lack of public legal awareness and intervention from third parties. For this reason, there is a need for socialization to the community about the importance of traffic awareness to minimize traffic accidents and also the need for socialization about restorative justice.

\section{References}

\section{Journal}


[1] Arman Sahti, Penerapan Konsep Restorative Justice Dalam Penyelesaian Perkara Kecelakaan Lalu Lintas, Aktualita, Vol. 2 No. 2 (December) 2019, url : https://ejournal.unisba.ac.id/index.php/aktualita/article/view/5176/pdf

[2] Dadik Purnomo dan Jawade Hafidz, Peran Sat Lantas Polres Rembang Dalam Menekan Angka Kecelakaan Lalu Lintas, Jurnal Daulat Hukum, Voume 1 No. 1 March, 2018, url http://jurnal.unissula.ac.id/index.php/RH/article/view/2647

[3] Hari Condro Wibowo, 2019, "Proses Penyidikan Pelaku Kecelakaan Lalu Lintas Anak di Bawah Umur di Kepolisian Resor Kebumen”, Tesis, Semarang : Unissula, h.4, url : http://repository.unissula.ac.id/16313/5/bab\%20I.pdf

[4] Mukhammad H. Saputra, "Analisis Sistem Informasi Faktor Risiko Kecelakaan Lalu Lintas di Dinas Kesehatan Kota Mojokerto", Medika Majapahit, Vol 8. No. 2, September 2016, url : https://123dok.com/document/zk6red8y-sekolahtinggi-ilmu-kesehatan-majapahit-mojokerto.html

[5] Preliyanto Puji Utomo and Bambang Tri Bawono, "Application Of Act No. 22 of 2009 As A Traffic Accidents Countermeasures Management In The Blora Police Law Area” Daulat Hukum, Vol 3 No. 2 (2020), url : http://jurnal.unissula.ac.id/index.php/RH/article/view/9373.

[6] Syakiar, Unit Pratimaratri, Deaf Wahyuni Ramadhani, Pelaksanaan Penyidikan Terhadap Anak Pelaku Pelanggaran Lalu Lintas Yang Mengakibatkan Korban Meninggal Dunia (Studi : Polresta Padang), Jurnal Penelitian, (http://www.ejurnal.bunghatta.ac.id, accessed on 20 May 2021).

[7] A Chuasanga, Ong Argo Victoria. (2019). Legal Principles Under Criminal Law in Indonesia Dan Thailand, Jurnal Daulat Hukum, Vol 2, No 1 (2019) http://jurnal.unissula.ac.id/index.php/RH/article/view/4218

\section{Book}

[1] Mukti Fajar ND dan Yulianto Achmad, 2013, Dualisme Penelitian Hukum Normatif dan Empiris, Yogyakarta: Pustaka Pelajar.

[2] M. Djunaidi Ghoni dan Fauzan Almansur, 2012, Metodologi Penelitian Kualitatif, ar-Ruzz Media, Yogyakarta.

[3] Nikmah Rosidah, 2014, Budaya Hukum Hakim Anak Di Indonesia, Semarang : Pustaka Magister, Semarang.

[4] P. Suwardjoko Warpani, 2002, Pengelolaan Lalu Lintas dan Agnkutan Jalan, Bandung : Penerbit ITB.

[5] Rudi Rizky (ed), 2008, Refleksi Dinamika Hukum (RangkaianPemikiran dalam Dekade Terakhir), Jakarta: Perum Percetakan Negara Indonesia.

\section{Regulations}

[1] Act No. 2 of 2002 concerning the Indonesian National Police.

[2] Act No. 22 of 2009 concerning Road Traffic and Transportation.

[3] Regulation of the Head of the National Police of the Republic of Indonesia Number 15 of 2013 concerning Procedures for Handling Traffic Accidents

[4] Regulation of the Head of the State Police of the Republic of Indonesia Number 6 of 2019 concerning Criminal Investigations. 


\section{Internet}

[1] Polda Jateng Kasus Kecelakaan Meninggal Terbanyak Terjadi di Tol, (https://news.detik.com, accessed on 20 May 2021)

[2] Tak Ada Tilang Kecelakaan Lalu Lintas di Rembang Turun, (https://radarkudus.jawapos.com, accessed on 20 May 2021). 